What are the feelings of the average Briton towards New Zealanders and towards the Empire generally?

They have none really. The Dominions can indulge in all sorts of imaginative illusions about the British Islands and even call them Home in their sentimental moments; but that side of life does not exist in England. Many Englishmen with astronomical tastes are keenly interested in the moon. Their interest in New Zealand may be guessed from a letter I had before starting from a lady who said she heard I was going to New Zealand and hoped I would stay with her daughter, who has a very nice house in Sydney!

\title{
New Zealand, 1934: II
}

From 'I'm More at Home Here', Auckland Star, 2 April 1934, reprinted in What I Said in NZ, p. 11. Unlike most of Shaw's written interviews, this was presented without disguise.

Writing to Wanganui from Walrakel. In reply to the question whether he observed that New Zealanders had developed separate national characteristics, Mr George Bernard Shaw said, 'No, it is the other way about. The characteristics of the British Islanders have changed so much in this century. They no longer resemble the Englishmen of the nineteenth century; New Zealanders resemble them very strongly, and consequently there is now a marked difference, but it is the Englishman who has changed, not the New Zealander. I, being an old Victorian, am much more at home here than in London. You are quite natural to me, but to the English visitor born after 1900 you probably appear quaint, foreign and incredible - but that is only my guess, since you ask me for one.'

Mr Shaw said the whole world was being Americanised by Hollywood, which, by the way, was not typically American. 'You must really learn to make your own talkies, or you will lose your souls without even getting American ones,' he said. 'The tendency is no worse in New Zealand than elsewhere, not anything like so strong as in British slums and suburbs.' 